\title{
Chemical Components of Ocimum basilicum L. and Ocimum tenuiflorum L. Stem Essential Oils and Evaluation of Their Antioxidant Activities Using DPPH Method
}

\author{
Ni Putu Ermi Hikmawanti, Hariyanti*, Nurkamalia, Sahera Nurhidayah \\ Faculty of Pharmacy and Sciences, Universitas Muhammadiyah Prof. DR. HAMKA, Jakarta, Indonesia
}

\begin{abstract}
Ocimum basilicum L. and Ocimum tenuiflorum L. are two types of plants from Ocimum (Lamiaceae). One of their chemical compounds is essential oil. Essential oil might have an antioxidant activities. The part of the plants which are often wasted and never used are stem. This study aimed to analyze the chemical components of $O$. basilicum L. and O. tenuiflorum L. stem essential oils and evaluate their antioxidant activities. Essential oils were obtained by steam-water distillation. Analysis of chemical component of essential oil was performed using Gas Chromatography-Mass Spectroscopy (GC-MS). Antioxidant activities were evaluated with $\mathrm{DPPH}$ method and then the $\mathrm{IC}_{50}$ value was determined as $50 \%$ inhibition concentration of free radical. The results showed that $O$. basilicum $\mathrm{L}$. stem essential oil had 13 components with the major compounds were methyl eugenol (52.60\%), caryophyllene (18.75\%), and germacrene-D $(9.19 \%)$. Whereas, O. tenuiflorum L. stem essential oil had 11 components with the major compounds were $\alpha$-copaene $(5.56 \%)$, caryophyllene $(17.28 \%)$, germacrene-D $(9.29 \%)$ and methyl eugenol (56.72\%). $\mathrm{IC}_{50}$ value of $O$. basilicum $\mathrm{L}$. stem essential oil was $17.50 \mu \mathrm{g} / \mathrm{mL}$, whereas $\mathrm{IC}_{50}$ value of $O$. tenuiflorum L. stem essential oil was $14.17 \mu \mathrm{g} / \mathrm{mL}$. It was concluded that both oils might be good natural antioxidant agents.
\end{abstract}

*Corresponding author Keywords: antioxidant; essential oils; Ocimum basilicum L; Ocimum tenuiflorum L; stem

Email: hariyanti.irawan@gmail.com

\section{INTRODUCTION}

Four or five species of Ocimum spp. grow in Indonesia. Two of the five species are distinct and should be relatively easy to identify. Whereas, the other two (or three) species are more similar in appearance. $O$. basilicum L. can be identified because it has the largest flowers of any basil found in Indonesia. Stems and leaves are glabrous (smooth, without hairs) or only minutely hairy. O. tenuiflorum L. is often encountered under the synonym $O$. sanctum $\mathrm{L}$. It has been described as a shortlived perennial and a dwarf shrub (or subshrub). It is much branched (Mead, 2014).

Ocimum tea is efficacious to expel gases, overcome stomach cramps, constipation, diarrhea and vomiting. It is also useful for treating mental fatigue, nervous conditions and hyssop for cough (Marwat et al., 2011). Indonesian people mostly use leaves of $O$. basilicum $\mathrm{L}$. as fresh vegetables. O. tenuiflorum $\mathrm{L}$. are also used as a spice in cooking because the aroma can reduce the fishy smell of wet fish. While the stem of this plant is often wasted and not used.

O. basilicum L. plant contains essential oils, triterpene, alkaloids, flavonoids, saponins, coumarin, steroids, gycoside and tannins. The essential oils contain monoterpene hydrocarbons, oxygenated monoterpene, sesquiterpene hydrocarbons and oxygenated sesquiterpene (Marwat et al., 2011). Whereas, the main chemical components in $O$. tenuiflorum L. are oleanolic acid, ursolic acid, rosmarinic acid, eugenol, carvacol, linalool and caryophyllene (Ravi et al., 2012).

Essential oils are natural plant products that have various biological properties. Essential oils contain volatile compounds (mainly mono- and sesquiterpenoids, benzenoids, phenylpropanoids, etc.) (Baser and Buchbauer, 2010). This oil is produced from certain parts of plant, such as roots, stems, skin, leaves, flowers and seeds (Gunawan and Mulyani 2004; Lutony and Rahmayati, 1994). Essential oils extracted from Ocimum plants have been applied to inhibit growth of microorganisms, in perfumery, in food preservation and also in aromatherapy (Pandey et al., 2014). A large number of studies on the antioxidant potential of essential oils are aimed at obtaining natural non-toxic antioxidants. Several compounds, such as eugenol, $\alpha$-pinene, terpinene, phellandrene, etc., are example of chemical components of essential oils that are thought to be related to the antioxidant activity (Amorati et al., 2013).

Studying volatile constituent components can be done by profiling the oil metabolites using the gas chromatography-mass spectrometry method. In addition, the process of determining secondary metabolites with certain characteristics is related to the response and mechanism of a drug (Saifudin et al., 2011). Thus, this 
study aimed to analyze the chemical components of $O$. basilicum L. and $O$. tenuiflorum L. stem essential oils and evaluate their antioxidant activities.

\section{METHODS}

\section{Plant Collection and Identification}

Samples were collected from the Indonesian Spices and Medicinal Crops Research Institute (ISMCRI)/Balai Penelitian Tanaman Rempah dan Obat (BALITTRO), Bogor, West Java. All samples then were identified in Herbarium Bogoriense, Biology Research Center, Indonesian Institute of Sciences/Lembaga Ilmu Pengetahuan Indonesia (LIPI), Cibinong.

\section{Extraction of Essential Oils}

The extraction process was carried out in the BALITTRO, Bogor, West Java. $12 \mathrm{~kg}$ of fresh $O$. basilicum L. stem and $20 \mathrm{~kg}$ of fresh $O$. tenuiflorum L. stem were extracted separately using the steam-water distillation for 6 hours. Essential oils were obtained then added with anhydrate $\mathrm{Na} 2 \mathrm{SO} 4$ to obtain pure essential oils. Essential oils were then analyzed for their characteristics including organoleptic parameters, yield percentages, specific gravity, refractive index and solubility in absolute alcohol.

\section{Analysis of Essential Oils}

Analysis of essential oils was carried out in the BALITTRO, Bogor, West Java. $10 \mu \mathrm{L}$ of the Ocimum essential oil were mixed with $1 \mathrm{~mL}$ of GC grade $\mathrm{n}$-hexane. One $\mu \mathrm{L}$ of the mixture was analyzed with the Gas Chromatography with Auto Sampler (Agilent Technologies 7890), 5975 Mass Selective Detector and Chemstation data system. Separation was carried out using the capillary column (Innowax HP) with length of $30 \mathrm{~m} \times 0.25 \mathrm{~mm}$ and film thickness of $0.25 \mu \mathrm{m}$. The carrier gas was helium gas at a constant flow rate of 0.6 $\mathrm{mL} / \mathrm{min}$. The injector temperature was set at $250{ }^{\circ} \mathrm{C}$. The initial temperature of the oven was set at $60^{\circ} \mathrm{C}$ then hold for $0 \mathrm{~min}$, rising at $2{ }^{\circ} \mathrm{C} / \mathrm{min}$ to $150{ }^{\circ} \mathrm{C}$ then hold for 1 min and finally rising at $20^{\circ} \mathrm{C} / \mathrm{min}$ to $210{ }^{\circ} \mathrm{C}$ then hold for $10 \mathrm{~min}$. According to Herebian et al. (2009), the main compounds in the GC-MS chromatogram have criteria for percent area $>5 \%$ of essential oils. The similarity of mass spectra of sample with a library was determined at a qualifier value of at least $80 \%$. The components was identified based on compatibility with an authentic mass spectrum in Wiley electronic library.

\section{DPPH Radical Scavenging Activity}

The free radical scavenging activity assay using the 1,1-diphenyl-2-picryl-hydrazyl (DPPH) reagent was determined according to Brand-Williams et al. (1995). $0.3 \mathrm{~mL}$ of $100 \mu \mathrm{g} / \mathrm{mL}$ of essential oil was reacted with $0.5 \mathrm{~mL}$ of DPPH $0.1 \mathrm{mM}$ solution in ethanol and $1.5 \mathrm{~mL}$ of absolute ethanol. The solution was incubated in the dark at room temperature for $30 \mathrm{~min}$. The decolorizing (from deep violet to light yellow) process was read at $516 \mathrm{~nm}$ using UV-VIS Spectrophotometer (Shimadzu) and compared with a blank control. For comparison, activities of Vitamin E standard was evaluated.

In the analytical procedure, the measurements were performed at four points of concentration, including control. The measurement of the DPPH radical scavenging activity of sample solution was repeated three times at each concentration. The results were expressed as percentage of decrease of DPPH radical. DPPH DPPH inhibition percentage is calculated using the following formula:

Inhibition ratio $(\%)=[($ absorbance of control-absorbance of sample)/absorbance of control x $100 \%)]$

The sample concentrations $(x)$ were plotted against the inhibition ratios $(y)$ and then the regression line equation $(y=b x \pm a)$ was obtained. The calculation of $50 \%$ of the inhibiton concentration of DPPH radical is obtained by entering 50 on $y$ in the regression line equation, so $x$ is the $\mathrm{IC}_{50}$ value.

\section{RESULTS AND DISCUSSION}

Extraction yields of $O$. basilicum L. and $O$. tenuiflorum L. stem essential oils are shown in Table 1. Oil contents $(\% \mathrm{v} / \mathrm{w})$ in fresh stems of $O$. basilicum L. and $O$. tenuiflorum L. were $0.183 \%$ and $0.200 \%$, respectively. Characteristics of essential oils are shown in Table 2. Chromatograms of $O$. basilicum L. and O. tenuiflorum L. stem essential oils are shown in Figure 1 and Figure 2. O. basilicum L. stem essential oil had 13 components. The major chemical constituents $(>5 \%)$ from this oil were methyl eugenol $(52.60 \%)$, caryophyllene $(18.75 \%)$ and germacrene-D (9.19\%). Whereas, O. tenuiflorum L. stem essential oil had 11 components with the major compounds were $\alpha$-copaene $(5.56 \%)$, caryophyllene (17.28\%), germacrene-D (9.29\%) and methyl eugenol $(56.72 \%)$. Chemical constituents of the essential oils are shown in Table $3 . \mathrm{IC}_{50}$ values of DPPH radical from $O$. basilicum L. and $O$. tenuiflorum L. stem essential oils were $17.50 \mu \mathrm{g} / \mathrm{mL}$ and $14.17 \mu \mathrm{g} / \mathrm{mL}$, respectively. Whereas, the $\mathrm{IC}_{50}$ value of Vitamin $\mathrm{E}$ was obtained at $30.89 \mu \mathrm{g} / \mathrm{mL}$.

In term of composition, essential oil of the stem is different from essential oil of aerial parts. Essential oils from $O$. basilicum L. aerial parts from Cianjur, West Java were reported to contain $4.88 \%$ methyl eugenol. On the other hand, the essential oil of O. tenuiflorum L. has a content of methyl eugenol of $8.69 \%$ (Sulianti, 2008). O. basillicum essential oil from China, Croatia, Israel, Republic of Guinea, Nigeria, Egypt, Pakistan and Malaysia was reported having a major component 
Table 1. Extraction yield of $O$. basilicum L. and $O$. tenuiflorum L. stem essential oils

\begin{tabular}{lll}
\hline Sample & Weight of fresh stem $\mathbf{( K g )}$ & Volume of essential oil $(\mathbf{m L})$ \\
\hline O. basilicum L & 12 & 22 \\
O. tenuiflorum L & 10 & 20 \\
\hline
\end{tabular}

Table 2. Characteristics of $\boldsymbol{O}$. basilicum L. and $\boldsymbol{O}$. tenuiflorum L. stem essential oils

\begin{tabular}{|c|c|c|c|}
\hline \multirow{2}{*}{ Parameters } & \multicolumn{2}{|l|}{ Essential Oils } & \multirow{2}{*}{$\begin{array}{l}\text { Essential Oil } \\
\text { Association of } O . \\
\text { basilicum } \\
\text { Essential Oil } \\
\text { (Hadipoentyanti and } \\
\text { Sri, 2018) }\end{array}$} \\
\hline & $\begin{array}{l}\text { O. basiliscum L. } \\
\text { stem }\end{array}$ & $\begin{array}{l}\text { o. tenuiflorum L. } \\
\text { stem }\end{array}$ & \\
\hline \multicolumn{4}{|l|}{ Organoleptic } \\
\hline Shape & Liquid & Liquid & - \\
\hline Colour & Brownish yellow & Pale yellow & Light yellow \\
\hline Odor & Specific & Specific & -0 \\
\hline Taste & Tighten & Bitter & - \\
\hline Yield percentage & $0.183 \%(\mathrm{v} / \mathrm{w})$ & $0.200 \%(\mathrm{v} / \mathrm{w})$ & - \\
\hline Refractive index & 1.2906 & 1.3493 & $1.510-1.5165$ \\
\hline $\begin{array}{l}\text { Specific gravity } \\
(\mathrm{g} / \mathrm{mL})\end{array}$ & 0.98054 & 1.0108 & $0.952-0.973$ \\
\hline $\begin{array}{l}\text { Solubility in } \\
\text { absolute alcohol }\end{array}$ & 1:1 (soluble) & 1:1 (soluble) & 4:1 (soluble) \\
\hline
\end{tabular}

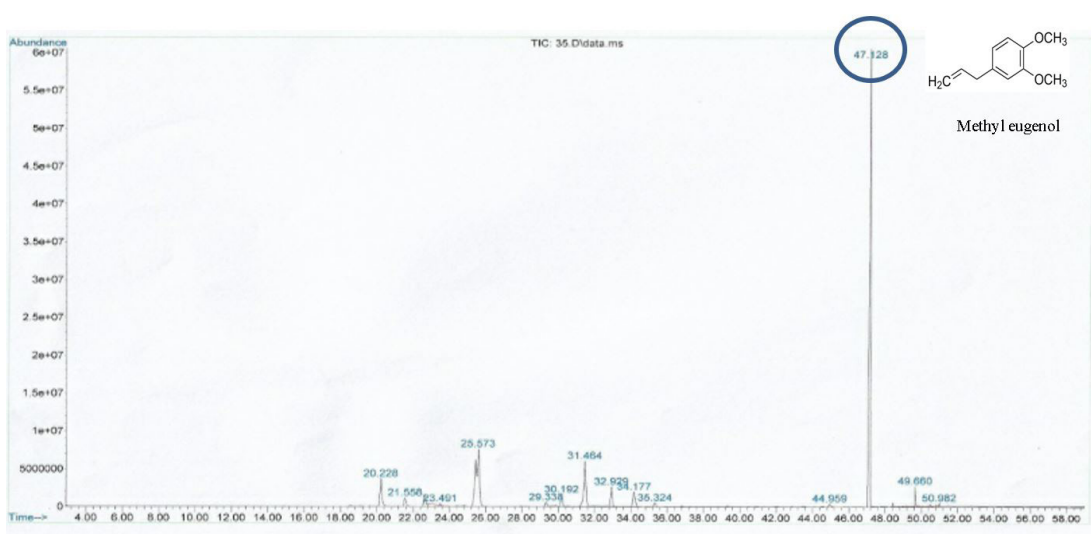

Figure 1. Chromatogram of $\boldsymbol{O}$. basilicum L. stem essential oil

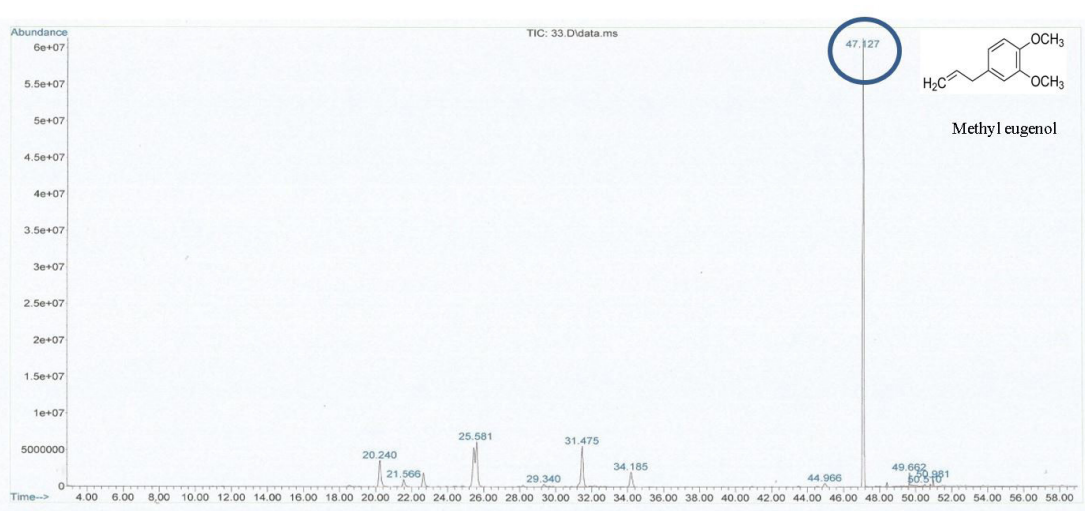

Figure 2. Chromatogram of $O$. tenuiflorum L. stem essential oil 
Table 3. Chemical components of $O$. basilicum $\mathrm{L}$. and $O$. tenuiflorum $\mathrm{L}$. stem essential oils

\begin{tabular}{|c|c|c|c|c|}
\hline Samples & $\mathbf{R t}$ & Quality & Compounds & $\begin{array}{l}\text { Percentage } \\
(\%)\end{array}$ \\
\hline \multirow[t]{13}{*}{ O. basilicum L. Stem Essential Oils } & 20.230 & 99 & $\alpha$-copaene & 4.93 \\
\hline & 21.559 & 99 & $\beta$-bourbonene & 1.58 \\
\hline & 23.492 & 95 & linalool & 1.58 \\
\hline & 25.573 & 99 & Caryophyllene & 18.75 \\
\hline & 29.340 & 99 & $\beta$-selinene & 0.81 \\
\hline & 30.192 & 97 & z-citral & 2.37 \\
\hline & 31.464 & 99 & Germacrene-D & 9.19 \\
\hline & 32.930 & 96 & e-citral & 3.39 \\
\hline & 34.178 & 91 & d-gurjunene & 3.16 \\
\hline & 44.959 & 93 & Caryophyllene oxide & 0.64 \\
\hline & 47.126 & 98 & Methyl eugenol & 52.6 \\
\hline & 49.659 & 98 & Eugenol & 2.4 \\
\hline & 50.983 & 98 & 1,3-benzodioxole & 0.75 \\
\hline \multirow[t]{11}{*}{ O. tenuiflorum L. Stem Essential Oils } & 20.239 & 99 & $\alpha$-copaene & 5.56 \\
\hline & 21.568 & 99 & $\beta$-bourbonene & 1.64 \\
\hline & 25.582 & 99 & Caryophyllene & 17.28 \\
\hline & 29.340 & 99 & $\alpha$-Humulene (CAS) & 0.76 \\
\hline & 31.473 & 99 & Germacrene-D & 9.29 \\
\hline & 34.187 & 94 & Germacrene-A & 3.52 \\
\hline & 44.968 & 93 & Caryophyllene oxide & 0.86 \\
\hline & 47.126 & 99 & Methyl eugenol & 56.72 \\
\hline & 49.664 & 98 & Eugenol & 3.17 \\
\hline & 50.511 & 97 & t-Murolol & 0.41 \\
\hline & 50.983 & 98 & 1,3-benzodioxole & 0.79 \\
\hline
\end{tabular}

Note: The percentage of components is the relative percentage calculated based on the area of the peak

of linalool, eugenol, 1,8-cineol, estragol, limonene, bergamotene, $\alpha$-cadinol, methyl cinnamate, and $(\mathrm{z})$ cinnamic acid methyl ester (Khair-ul-Bariyah et al., 2012). In another study, it was stated that the eugenol content in the oil was quite high $(10-19 \%)$, whereas methyl eugenol was a minor compound $(<5 \%)$ (Zamfirache et al., 2011). All O. basilicum L. essential oils of the leaves from different regions in the Kingdom of Saudi Arabia contain $\beta$-Linalool (9.12-72.59\%) and 1,8 Cineole (0.4-10.72\%) as the main compounds. While, the content of methyl eugenol in all of the samples was recorded in the range of $0.27-18.39 \%$ (Ladwani et al., 2018). In O. tenuiflorum L., eugenol (25.3-51.5\%) was a major constituent followed by caryophyllene (1.2$25.4 \%$ ) (Sims et al., 2013). The contents of methyl eugenol as the major constituent in essential oils from whole herb, leaves, stems and inflorescences of $O$. tenuiflorum L. were $72.5 \%, 75.3 \%, 83.7 \%$ and $65.2 \%$, respectively. Whereas, the respective concentrations of $\beta$-caryophyllene as second most dominant constituent in the essential oils were $5.5 \%, 6.4 \%, 2.7 \%$ and $12.0 \%$ (Kothari, 2014).

Comparison of components of essential oils from stems of these two plants shows a slight similarity, both contain high amounts of methyl eugenol. Methyl eugenol is an oxygenated compound. Macchia et al. (2006) reported that methyl eugenol, produced up to $8 \%$ in the vegetative stage, was only found in some of the cultivars. Methyl eugenol is formed through cyclic acid pathways, where phenylalanine is the precursor. Through a few reaction stage, eugenol will be formed. With methyl donor from Sadenosylmethionine (SAM) and enzymatic activity from O-methyltransferase (OMT), eugenol is then converted to methyl eugenol (Murningsih et al., 2009).

The intensity of antioxidant activities of essential oils from $O$. basilicum L. and $O$. tenuiflorum L. stem was classified as very strong antioxidant $(<50 \mu \mathrm{g} / \mathrm{mL})$. Ocimum plants contain large amounts of antioxidants, 
such as flavonoids, carotenoids, vitamin C, and vitamin E. The presence of antioxidant compounds provides protection against free radical which can cause oxidative damage of cellular component (Pandey et al., 2014). Natural essential oils contain several components. When they are used to protect some material, their activity is thought to be due to the dominance of the effective content of certain components therein. This is true in some cases. However, there are some exceptions. The antioxidant activity of essential oil, in fact, is also the result of the complex interplay among components and material to be protected from oxidation (Amorati, 2013).

\section{CONCLUSION}

Based on our results, there is a similarity in the chemical composition between $O$. basilicum L. and O. tenuiflorum L. stem essential oils. Methyl eugenol is a major compound that is produced by Ocimum and it might have a role in their antioxidant activities. These findings suggest that both oils might be good natural antioxidant agents.

\section{ACKNOWLEDGEMENT}

We thank to the Research Institute and Development of Universitas Muhammadiyah Prof. DR. HAMKA, Jakarta, for Funding Research Grants Development of Science and Technology Batch I 2019.

\section{REFERENCES}

Amorati R, Foti MC \& Valgimigli L, (2013), Antioxidant Activity of Essential Oils, Journal of Agricultural and Food Chemistry, 61(46), 10835-10847

Baser KHC \& Buchbauer G. (2010). Handbook of essential oils: science, technology, and applications. New York: CRC Press Taylor \& Francis Group, 1-5

Brand-Williams W, Cuvelier ME \& Berset C. (1995). Use a Free Radical Method to Evaluate Antioxidant Activity. Lebensm. Wiss. Technol., 28, 25-30

Gunawan D \& Mulyani S. 2004. Ilmu Obat Alam (Farmakognosi). Ed I. (In Bahasa). Jakarta: Penebar Swadaya, 108-120.

Hadipoentiyanti E \& Sri W. (2008). Keragaman Selasih (Ocimum Spp.) Berdasarkan Karakter Morfologi, Produksi Dan Mutu Herba (In Bahasa). Jurnal Littri, 142-146.

Herebian D, Choi J-H, El-Aty AMA,Shim J-H \& Spiteller M. (2009). Metabolite analysis in Curcuma domestica using various GC-MS and LC-MS separation and detection techniques. Biomed. Chromatogr, 23, 951-965.

Khair-ul-Bariyah S, Ahmed D \& Ikram M. (2012). Ocimum Basilicum: A Review on Phytochemical and Pharmacological Studies. Pak.J.Chem, 2(2), 78-85.

Kothari SK, Bhattacharya AK, Ramesh S, Garg SN, Khanuja S. (2014). Volatile Constituents in Oil from Different Plant Parts of Methyl Eugenol-Rich Ocimum tenuiflorum L.f. (syn. O.sanctum L.) Grown in South India. Journal of Essential Oil Research, 17(6), 656-658

Ladwani AMA, Salman M \& Abdel Hameed ES. (2018). Chemical composition of Ocimum basilicum L. essential oil from different regions in the Kingdom of Saudi Arabia by using Gas chromatography mass spectrometer. Journal of Medicinal Plants Studies, 6(1), 14-19.

Lutony TL \& Rahmayati Y. (1994). Produksi Dan Perdagangan Minyak Atsiri. (In Bahasa). Jakarta: Penebar Swadaya, 112-113.

Macchia M, Pagano A, Ceccarini L, Benvenuti S, Cioni PL \& Flamini G. (2006). Agronomic and phytochimic characteristics in some genotypes of Ocimum basilicum L. Acta Hort., 723, 143-149.

Marwat SK, Fazal-Ur-Rehman, Khan MS, Ghulam S, Anwar N, Mustafa G \& Usman K. (2011). Phytochemical Constituents and Pharmacological Activities of Sweet Basil-Ocimum basilicum L. (Lamiaceae). Asian Journal of Chemistry, 23(9), 3773-3782.

Mead D. (2014). Basils (Ocimum spp.) in Indonesia. Sulawesi: Sulang Language: Data and Working Papers; Topics in Lexicography, 3-5.

Murningsih T, Chairul, \& Kuncari ES. (2009). Methyl Eugenol, Chemotype of essential Oils of Melaleuca spp. (Myrtaceae) Growing in Cibodas Botanical Garden. (In Bahasa) Berita Biologi, 9(6), 809-816.

Pandey AK, Singh P \& Tripathi NN. (2014). Chmistry and Bioactivities of Essential Oils of Some Ocimum Species: An Overview. Asian Pasific Journal of Tropical Biomedicine, 4(9), 682-694.

Ravi P, Elumalai A, Eswaraiah MC \& Kasarla R. (2012). A Review on Krishna Tulsi, Ocimum tenuiflorum Linn. IJRAP 3(2), 291-293.

Saifudin A, Rahayu V, \& Teruna HY. (2011). Standarisasi bahan obat alam. (In Bahasa), Yogyakarta: Graha Ilmu, 90-93. 
Sims CA, Juliani HR, Mentreddy SR \& Simon JE. (2013). Essential Oils in Holy Basil (Ocimum tenuiflorum L.) as Influenced by Planting Dates and Harvest Times in North Alabama. Journal of Medicinally Active Plants, 2(3), 33-41.

Sulianti SB. (2008). Phytochemical Study of Ocimum spp.: Chemical Components of Essential Oils of Kemangi and Ruku-Ruku. (In Bahasa) Berita Biologi, 9(3), 237-241.

Zamfirache MM, Padurariu C, Burzo I, Olteanu Z, Boz I \& Lamban C. (2011). Research Regarding the Chemical Composition of the Volatile Oil of Some Taxa Belonging to the Genus Ocimum, Biologie vegetală, 31-34. 